\title{
ISLAMIC CORPORATE GOVERNANCE DALAM LAPORAN TAHUNAN BANK SYARIAH DI INDONESIA
}

\author{
Ari Sita Nastiti \\ Program Studi Akuntansi Universitas Muhammadiyah Jember \\ arisitanastiti@unmuhjember.ac.id
}

\begin{abstract}
This study analyzed the level of Islamic Corporate Governance (ICG) disclosure in the annual report of Islamic banking in Indonesia. The level of ICG disclosure was measured using the Corporate Governance Disclosure Index (CGDI) developed by Darmadi (2013). This study used 12 Islamic Commercial Banks (BUS) with a total of 36 Annual Reports during the 2014-2016 period as samples. This study is written using a qualitative descriptive approach. The technique of data analysis is content analysis methods with dichotomous procedures. Based on the data analysis during the observation period, the results show that the ICG disclosure rate in the annual reports of Sharia Commercial Banks reaches an average score of $84.3 \%$ with a trend that increases per year. However, the improvement of the implementation of good corporate governance that in accordance with sharia principles must continue to be implemented by Islamic banks as a sharia entity to realize accountability to Allah SWT and to realize Maqashid Shariah.
\end{abstract}

\section{Keywords: Annual Report, Disclosures, Islamic banking, Islamic Corporate Govenance, Sharia Entity}

\section{PENDAHULUAN}

Pada tahun 1991, Bank Muamalat Indonesia (BMI) didirikan atas dasar inisiasi masyarakat muslim di Indonesia yang menginginkan sistem perbankan tanpa bunga. Kemampuan Bank Muamalat Indonesia menghadapi krisis ekonomi di tahun 1998, menarik minat masyarakat dan para investor terhadap sistem perbankan syariah. Terlebih semenjak disahkannya UU No. 21 tahun 2008 tentang Perbankan Syariah sebagai landasan hukum yang lebih kuat bagi pengembangan industri perbankan syariah di tanah air (OJK, 2017).

Jumlah entitas perbankan syariah pun mengalami peningkatan tiap tahunnya. Dari data Statistik Perbankan Syariah per Oktober 2017, tercatat terdapat 13 Bank Umum Syariah (BUS), 21 Unit Usaha Syariah (UUS) dan 167 Bank Pembiayaan Rakyat Syariah (BPRS) yang beroperasi di 
Indonesia. Di samping itu, nilai Aset, Pembiayaan yang Diberikan (PYD) dan Dana Pihak Ketiga (DPK) industri perbankan syariah nasional tercatat mengalami pertumbuhan yang cukup signifikan, dimana pada tahun 2016, total Aset mencapai Rp365,6 triliun, PYD Rp254,7 triliun dan DPK Rp285,2 triliun (OJK, 2017).

Perkembangan industri perbankan syariah di Indonesia yang cukup pesat, memacu tuntutan penerapan Good Corporate Governance yang sesuai dengan nilai-nilai islam. Mannan (1980) menyatakan bahwa tujuan bank syariah jauh lebih besar dibandingkan hanya untuk memaksimalkan laba, salah satunya adalah mewujudkan Maqashid Shariah. Untuk itu, dibutuhkan tata kelola sesuai prinsip syariah yang telah terstandarisasi sebagai pedoman bagi perbankan syariah.

Darmadi (2013) menyatakan bahwa tingkat signifikansi tata kelola perusahaan di industri perbankan lebih tinggi karena bank sangat bergantung pada kepercayaan publik dalam mengelola simpanan masyarakat serta memiliki stakeholder yang lebih beragam. Lemahnya tata kelola di bank telah mengakibatkan jatuhnya bank selama krisis, serta skandal keuangan yang melibatkan pemilik dan manajemen, yang dapat berdampak sistemik terhadap ekonomi.

Darmadi (2013) lebih lanjut mengungkapkan bahwa dalam perbankan syariah, perhatian yang lebih besar pada tata kelola perusahaan perlu dilakukan setidaknya untuk tiga alasan, yaitu: Pertama, bank syariah perlu mematuhi hukum syariah, selain mematuhi peraturan perbankan sehingga bank syariah lebih banyak terpapar dengan risiko ketidakpatuhan. Kedua, bank syariah memiliki pemegang rekening investasi yang tidak terbatas (Investment Account Holders/IAH), yang cenderung menjadi bagian dari konflik agensi karena mereka berpartisipasi dalam keuntungan dan kerugian seperti pemegang saham. Untuk itu, semua tindakan pencegahan perlu dilakukan untuk menjaga kepercayaan deposan pada bank syariah, karena ketika bank syariah gagal melindungi kepentingan deposan, maka deposan cenderung melindungi hak mereka dengan menarik simpanan mereka di bank. Ketiga, kebanyakan bank syariah beroperasi di pasar negara berkembang, di mana lingkungan 
institusional cenderung lebih lemah. Di pasar seperti itu, di mana konsentrasi kepemilikan dan kontrol keluarga tingkat tinggi lebih umum, peraturan yang berlaku cenderung kurang melindungi pemegang saham minoritas dari pengambilalihan aset oleh pemegang saham pengendali. Selain itu, praktik transparansi dan pengungkapan juga lebih lemah di pasar ini dibandingkan dengan ekonomi yang lebih maju, sehingga biaya pemantauan dan asimetri informasi lebih tinggi. Oleh karenanya, berdasarkan kondisi tersebut, maka perlu ditekankan pentingnya tata kelola yang baik di industri perbankan syariah.

Dalam upaya meningkatkan kualitas tata kelola perusahaan di sektor jasa keuangan syariah, pada tahun 2011 diterbitkanlah Pedoman Umum GGBS (Good Governance Bisnis Syariah) oleh KNKG (Komite Nasional Kebijakan Governance) sebagai pedoman dalam menjalankan usaha secara Islami bagi entitas syariah maupun entitas lain yang ingin menerapkannya (KNKG, 2011). Di samping diperlukan adanya pedoman Good Corporate Governance dari Badan Pengatur, hal lain yang menjadi perhatian khusus adalah kepatuhan institusi keuangan syariah terhadap ketentuan syariah dalam semua aspek operasinya.

Majid et al. (2011) mengungkapkan hal lainnya yang juga penting adalah kebutuhan untuk mengembangkan indeks pengungkapan tata kelola perusahaan yang komprehensif untuk institusi keuangan syariah guna mengevaluasi kualitas pengungkapan tata kelola institusi keuangan syariah. Oleh karenanya, beberapa peneliti mencoba mengembangkan indeks Islamic Corporate Governance dan menggunakannya untuk menilai penerapan tata kelola perusahaan yang berdasarkan nilai-nilai islam pada institusi keuangan syariah.

$$
\text { Jumansyah dan Syafei (2013) }
$$

menggunakan Indeks GGBS (Good Corporate Governance Bisnis Syariah) yang dikembangkannya berdasarkan pedoman Penerapan GGBS oleh KNKG untuk menguji tingkat penerapan ICG di Bank Muamalat dan Bank Syariah Mandiri (BSM) pada periode pengamatan 2009 - 2011. Penelitian tersebut menghasilkan kesimpulan bahwa rata-rata tingkat penerapan GGBS pada Bank Muamalat \& BSM sudah cukup baik, namun masih berfluktuatif dari tahun ke tahun. 
Penelitian lainnya juga dilakukan oleh Darmadi (2013), yang bertujuan untuk mengeksplor pengungkapan mekanisme ICG dalam 7 laporan tahunan BUS nasional periode tahun 2010, menggunakan indikator Corporate Governance Disclosure Index (CGDI) yang dikembangkannya sendiri. Hasil penelitian Darmadi (2013) menunjukkan bahwa Bank Muamalat dan BSM mendapat nilai lebih tinggi dari bank syariah lainnya.

Di Malaysia, Sulaiman et al. (2015) menguji tingkat penerapan ICG pada Islamic Financial Institution (IFI). Sulaiman et al. (2015) menggunakan checklist CGDI (Corporate Governance Disclosure Index) yang telah dikembangkannya dalam penelitian sebelumnya bersama Majid et al. (2011). Adapun hasil penelitian tersebut menunjukkan bahwa pengungkapan informasi ICG pada IFI di Malaysia dapat dianggap "baik", dengan rata-rata skor mencapai sebesar 51,42 persen.

Penelitian ini menganalisis tingkat pengungkapan Islamic Corporate Governance (ICG) pada perbankan syariah nasional, dengan harapan dapat memberikan kontribusi bagi pengembangan perekonomian islam di Indonesia.

\section{TINJAUAN PUSTAKA}

\subsection{Tata Kelola Perusahaan (Corporate Governance) dalam} Perspektif Syariah

Good Corporate Governance (GCG) menurut OECD (Organisation for Economic Co-operation and Development) merupakan sarana bagi perusahaan untuk membangun integritas bisnis dan kepercayaan pasar. Hal tersebut sangat dibutuhkan bagi perusahaan untuk dapat mengakses modal ekuitas yang digunakan untuk investasi jangka panjang (OECD, 2015). OECD merumuskan prinsipprinsip corporate governance sebagai referensi dalam membuat keputusan bagi pengambil kebijakan di suatu entitas, baik di negara - negara anggota OECD maupun di negara lainnya di dunia (Abu-Tapanjeh, 2009). Prinsipprinsip tersebut awalnya dikembangkan di tahun 2009, kemudian diperbarui di tahun 2004 dan terakhir di tahun 2015.

Dalam sudut pandang syariah, Choudury dan Hoque (2006) mengemukakan bahwa tata kelola perusahaan konvensional dan syariah memiliki perbedaan. Perbedaan yang utama terkait dengan ideologi, dimana perspektif syariah menggunakan 
ideologi tauhid sedangkan perspektif konvensional menggunakan ideologi rasionalisme dalam setiap aktivitas bisnisnya. Di samping itu, tujuan suatu perusahaan dalam perspektif syariah lebih kepada meningkatkan kesejahteraan ummat. Adapun dalam perspektif konvensional, tujuan perusahaan adalah senantiasa memaksimalisasi keuntungan (Choudury dan Hoque, 2006).

Sejak awal peradaban Islam berkembang, di dalam budaya Islam juga telah tertanam tata kelola perusahaan yang baik. Masyarakat muslim mempunyai pandangan dan nilai berbeda terkait tata kelola perusahaan. Keyakinan yang kuat mengenai akuntabilitas (pertanggungjawaban) kepada Allah SWT di dunia maupun di Hari Akhir, memiliki implikasi yang kuat dalam setiap kehidupan Muslim dan mengatur cakupan yang lebih luas mengenai kewajiban tata kelola perusahaan bila dibandingkan untuk prinsip konvensional. Hal ini dikarenakan ukuran kesuksesan dan kesejahteraan umat muslim berkaitan dengan kewajiban etis, moral dan spiritual berlandaskan keyakinan yang kuat terhadap

akuntabilitas (pertanggungjawaban) kepada Allah SWT, sebagai otoritas tertinggi (AbuTapanjeh, 2009).

\subsection{Islamic Corporate Governance}

Beberapa skandal besar yang melibatkan perusahaan-perusahaan ternama di dunia dalam beberapa tahun terakhir telah mengakibatkan meningkatnya perhatian pada pengungkapan tata kelola perusahaan. Demikian pula, perhatian yang besar telah diberikan untuk memperbaiki praktik tata kelola perusahaan di industri jasa keuangan Islam (Majid et al., 2011).

Charles dan Chariri (2013) menyatakan bahwa Islamic Corporate Governance terkait dengan keberadaan DPS (Dewan Pengawas Syariah) dan komposisi keahlian DPS. Menurut Charles dan Chariri (2013), dalam proses pengawasan di bank syariah, DPS memiliki peranan penting dikarenakan adanya kewewenangan untuk memberikan masukan dan peringatan kepada pihak manajemen terkait kepatuhan terhadap prinsip syariah dalam pengelolaan dan pengambilan kebijakan perusahaan. 
Selanjutnya untuk mendukung tugas utama DPS dalam hal sharia compliant, Akbar (2008) menyatakan bahwa DPS dituntut memiliki keahlian dalam hal hukum Islam, keuangan dan juga perbankan. Penguasaan hukum islam dan pemahaman praktik perbankan dibutuhkan guna menentukan (istimbat) kehalalan segala aktivitas bisnis perbankan syariah. Oleh karenanya komposisi keahlian DPS menjadi salah satu komponen yang diperlukan guna mendukung terwujudnya Islamic Corporate Governance (Charles dan Chariri, 2012).

Dalam upaya meningkatkan kualitas tata kelola perusahaan di sektor jasa keuangan, pada tahun 2011 diterbitkanlah Pedoman Umum Good Governance Bisnis Syariah (GGBS) oleh badan pengatur Komite Nasional Kebijakan Governance (KNKG) sebagai pedoman dalam menjalankan usaha secara Islami bagi entitas syariah maupun entitas lain yang ingin menerapkannya (KNKG, 2011).

Di samping diperlukan adanya pedoman Good Corporate Governance dari Badan Pengatur, hal lain yang menjadi perhatian khusus adalah kepatuhan institusi keuangan syariah terhadap ketentuan syariah dalam semua aspek operasinya. Majid et al. (2011) mengungkapkan hal lainnya yang juga penting adalah kebutuhan untuk mengembangkan indeks pengungkapan tata kelola perusahaan yang komprehensif untuk institusi keuangan syariah guna mengevaluasi kualitas pengungkapan tata kelola institusi keuangan syariah. Oleh karenanya, Majid et al. (2011) mencoba mengembangkan checklist Corporate Governance Disclosure Index (CGDI) untuk institusi keuangan syariah, berdasarkan pada tiga pedoman/standar yang dikeluarkan oleh Central Bank of Malaysia, Islamic Financial Services Board dan AOIIFI.

Indeks CGD yang dikembangkan oleh Majid et al. (2011) terdiri dari 14 dimensi yang dibagi menjadi dua bidang tata kelola, yaitu: 1. Informasi terkait tata kelola umum (generalgovernance related information/GCGi), yang biasanya diterapkan di perusahaan umum; dan 2. Informasi terkait tata kelola spesifik (specific-governance related information/SCGi), yang terkait dengan institusi keuangan syariah 
(Islamic Financial Institution). Sepuluh dimensi GCGi terdiri dari struktur dan fungsi dewan, komite nominasi, komite remunerasi, komite manajemen risiko, komite audit dan tata kelola, manajemen risiko, pengendalian dan audit internal, transaksi dengan pihak yang berelasi, laporan manajemen dan ketidakpatuhan terhadap pedoman. Sementara 4 dimensi SCGi, meliputi: Dewan Pengawas Syariah, Pemegang Rekening Investasi, komite tata kelola dan isu-isu yang berkaitan dengan kepatuhan Syariah. Secara keseluruhan, terdapat 123 item dalam 14 dimensi. Indeks CGD yang dikembangkan tersebut diharapkan dapat dijadikan tolok ukur untuk menentukan kualitas pengungkapan tata kelola institusi keuangan syariah.

Darmadi (2013) menyatakan bahwa mekanisme tata kelola perusahaan meliputi Dewan Pengawas Syariah, Dewan Komisaris, Direksi, komite dewan, pengendalian internal dan audit eksternal, manajemen risiko, dan pelaporan penerapan tata kelola perusahaan. Darmadi (2013) juga turut mengembangkan

Corporate Governance Disclosure Index (CGDI) untuk menilai tingkat pengungkapan tata kelola bank syariah. Item-item pengungkapan dalam CGDI dikembangkan oleh Darmadi (2013) secara hati-hati berdasarkan penelitianpenelitian terdahulu, seperti Haniffa dan Hudaib (2004, 2007) dan Kusumawati (2007), peraturan perbankan Indonesia, pedoman dari Islamic Financial Services Board (IFSB), serta beberapa item yang ditambahkan berdasarkan pertimbangan best practise.

\section{METODE PENELITIAN}

Penelitian ini termasuk dalam penelitian deskriptif kualitatif. Jenis data yang digunakan adalah data sekunder berupa laporan tahunan perusahaan sampel. Populasi penelitian meliputi semua perbankan syariah di Indonesia yang terdaftar di OJK. Metode purposive sampling digunakan sebagai metode dalam pengambilan sampel berdasarkan kriteria berikut:

a) Sampel merupakan Bank Umum Syariah (BUS) yang terdaftar di OJK selama periode 2014-2016.

b) BUS mempublikasikan Laporan Tahunan selama 3 tahun berturutturut pada periode 2014-2016. 
Penelitian ini menggunakan teknik analisis data berupa metode content analysis dengan prosedur dikotomi (dichotomous procedure). Metode content analysis telah umum dipakai dalam menguji material tertulis yang terkandung dalam laporan tahunan (Haniffa, 2002). Dimana, nilai 1 diberikan untuk setiap item pengungkapan, dan bila tidak diungkapkan diberi nilai 0 . Kemudian dilakukan penjumlahan atas seluruh skor item pengungkapan guna mendapatkan total skor dari masingmasing entitas.

Penelitian ini menggunakan Corporate Governance Disclosure Index (CGDI) yang dikembangkan oleh Darmadi (2013) guna mengukur tingkat pengungkapan ICG. CGDI meliputi 72 indikator dalam 7 dimensi mekanisme tata kelola perusahaan, yaitu: Dewan
Pengawas Syariah, Dewan Komisaris, Direksi, komite dewan, pengendalian internal dan audit eksternal, manajemen risiko, dan pelaporan penerapan tata kelola perusahaan. Indeks tersebut dikembangkan berdasarkan penelitianpenelitian terdahulu, seperti Haniffa dan Hudaib (2004, 2007) dan Kusumawati (2007), peraturan perbankan Indonesia, pedoman dari Islamic Financial Services Board (IFSB), serta beberapa indikator yang ditambahkan berdasarkan pertimbangan best practise. Oleh karenanya, CGDI dianggap tepat guna menilai tingkat penerapan ICG pada perbankan syariah nasional karena pengembangannya berlandaskan pedoman dan kondisi yang terjadi di Indonesia.

Tingkat ICG diukur sebagaimana penelitian sebelumnya (Darmadi, 2013), yaitu:

$$
\mathrm{ICG}=\frac{\text { Total skor pengungkapan yang dipenuhi }}{\text { Total skor maksimum }}
$$




\section{HASIL DAN PEMBAHASAN}

\subsection{Distribusi Sampel Penelitian}

Tabel 1. Sampel Penelitian

\begin{tabular}{|l|l|c|c|c|}
\hline No. & \multicolumn{1}{|c|}{ Keterangan } & $\begin{array}{c}\text { Tahun } \\
\mathbf{2 0 1 4}\end{array}$ & $\begin{array}{c}\text { Tahun } \\
\mathbf{2 0 1 5}\end{array}$ & $\begin{array}{c}\text { Tahun } \\
\mathbf{2 0 1 6}\end{array}$ \\
\hline 1. & Perbankan syariah yang terdaftar di OJK & 197 & 197 & 200 \\
\hline 2. & $\begin{array}{l}\text { Perbankan syariah yang tidak termasuk Bank } \\
\text { Umum Syariah }\end{array}$ & $(185)$ & $(185)$ & $(187)$ \\
\hline 3. & $\begin{array}{l}\text { Bank Umum Syariah yang tidak } \\
\text { mempublikasikan Laporan Tahunannya } \\
\text { selama 3 tahun berturut-turut }\end{array}$ & $(0)$ & $(0)$ & $(1)$ \\
\hline \multicolumn{1}{|c|}{ Sampel akhir penelitian } & $\mathbf{1 2}$ & $\mathbf{1 2}$ & $\mathbf{1 2}$ \\
\hline
\end{tabular}

Sumber: www.ojk.go.id (Data diolah)

Populasi penelitian ini adalah seluruh entitas perbankan syariah yang terdaftar di OJK periode 2014-2016, meliputi BUS, UUS dan BPRS. Berdasarkan Tabel 1, terlihat bahwa jumlah perbankan syariah yang termasuk dalam kriteria sampel adalah sebanyak 12 BUS dengan total 36 Laporan Tahunan selama periode pengamatan.

Daftar BUS yang digunakan sebagai sampel penelitian tercantum dalam Tabel 2 berikut:

Tabel 2. Daftar Sampel Penelitian

\begin{tabular}{|c|c|l|}
\hline NO & KODE & \multicolumn{1}{|c|}{ PERUSAHAAN } \\
\hline 1 & BBMI & PT. Bank Muamalat Indonesia \\
\hline 2 & BVCS & PT. Bank Victoria Syariah \\
\hline 3 & BRIS & PT. Bank BRISyariah \\
\hline 4 & BJBS & PT. Bank Jabar Banten Syariah \\
\hline 5 & BNIS & PT. Bank BNI Syariah \\
\hline 6 & BBSM & PT. Bank Syariah Mandiri \\
\hline 7 & BMGS & PT. Bank Mega Syariah \\
\hline 8 & PNBS & PT. Bank Panin Dubai Syariah \\
\hline 9 & BSBU & PT. Bank Syariah Bukopin \\
\hline 10 & BCAS & PT. BCA Syariah \\
\hline 11 & MYBS & PT. Maybank Syariah Indonesia \\
\hline 12 & BTPS & PT. Bank Tabungan Pensiunan Nasional Syariah \\
\hline
\end{tabular}

Sumber: Data Diolah 
4.3 Hasil Content Analysis Tingkat

Islamic Corporate Governance (ICG)

Penelitian ini menggunakan 72 indikator Corporate Governance Disclosure Index (CGDI) yang dikembangkan oleh Darmadi (2013) dalam menilai tingkat pengungkapan ICG perusahaan sampel. Hasil analisa isi (Content Analysis) mengenai tingkat pengungkapan ICG perusahaan sampel ditunjukkan pada Tabel 3 di bawah ini:

Tabel 3 Tingkat Pengungkapan ICG Bank Umum Syariah (BUS)

Periode 2014 -2016

\begin{tabular}{|c|l|c|c|c|c|c|}
\hline NO & KODE & $\mathbf{2 0 1 4}$ & $\mathbf{2 0 1 5}$ & $\mathbf{2 0 1 6}$ & Rata-Rata & \% \\
\hline 1 & BBMI & 65 & 67 & 65 & 65,7 & $91,2 \%$ \\
\hline 2 & BVCS & 54 & 54 & 58 & 55,3 & $76,9 \%$ \\
\hline 3 & BRIS & 57 & 59 & 67 & 61,0 & $84,7 \%$ \\
\hline 4 & BJBS & 50 & 53 & 61 & 54,7 & $75,9 \%$ \\
\hline 5 & BNIS & 66 & 66 & 70 & 67,3 & $93,5 \%$ \\
\hline 6 & BBSM & 66 & 64 & 67 & 65,7 & $91,2 \%$ \\
\hline 7 & BMGS & 50 & 50 & 65 & 55 & $76,4 \%$ \\
\hline 8 & PNBS & 61 & 63 & 65 & 63 & $87,5 \%$ \\
\hline 9 & BSBU & 58 & 63 & 63 & 61,3 & $85,2 \%$ \\
\hline 10 & BCAS & 58 & 59 & 58 & 58,3 & $81,0 \%$ \\
\hline 11 & MYBS & 58 & 61 & 63 & 60,7 & $84,3 \%$ \\
\hline 12 & BTPS & 60 & 59 & 61 & 60 & $83,3 \%$ \\
\hline \multicolumn{2}{|c|}{ Rata-rata } & $\mathbf{5 8 , 6}$ & $\mathbf{5 9 , 8}$ & $\mathbf{6 3 , 6}$ & $\mathbf{6 0 , 7}$ & $\mathbf{8 4 , 3 \%}$ \\
\hline
\end{tabular}

Sumber: Data Diolah 
Tabel 3 menunjukkan bahwa BUS dengan tingkat pengungkapan ICG tertinggi adalah Bank Negara Indonesia Syariah (BNIS). BNIS memiliki ratarata skor ICG sebesar 67,3 $(93,5 \%)$ dari total 72 indikator checklist ICG, dengan rincian skor yang sama di tahun 2014 dan 2015 (skor $=66$ ) dan kemudian meningkat menjadi 70 di tahun 2016. Disusul kemudian oleh 2 BUS tertua yakni Bank Muamalat (BBMI) dan Bank Syariah Mandiri (BBSM) di posisi kedua dengan nilai rata-rata skor ICG yang sama, yaitu: 65,7 (91,2\%). Adapun BUS dengan pengungkapan ICG terendah adalah Bank Jabar dan Banten Syariah (BJBS) dengan rata-rata persentase ICG mencapai 54,7 atau $75,9 \%$ dari total 72 indikator checklist ICG.

Selanjutnya, Tabel 4 di bawah ini menyajikan informasi mengenai persentase skor ICG berdasarkan dimensi pengungkapan.

Tabel 4.

Tingkat Pengungkapan ICG Berdasarkan Dimensi Periode 2014 -2016

\begin{tabular}{|c|l|c|c|c|c|}
\hline No & Dimensi & $\mathbf{2 0 1 4}$ & $\mathbf{2 0 1 5}$ & $\mathbf{2 0 1 6}$ & Rata-rata \\
\hline 1 & Dewan Pengawas Syariah & $15,0 \%$ & $14,4 \%$ & $15,9 \%$ & $15,1 \%$ \\
\hline 2 & Dewan Komisaris & $15,9 \%$ & $16,0 \%$ & $17,4 \%$ & $16,4 \%$ \\
\hline 3 & Dewan Direksi & $11,6 \%$ & $11,6 \%$ & $12,4 \%$ & $11,8 \%$ \\
\hline 4 & Dewan Komite & $15,4 \%$ & $16,7 \%$ & $16,8 \%$ & $16,3 \%$ \\
\hline 5 & Pengendalian Internal dan Audit Eksternal & $6,5 \%$ & $7,4 \%$ & $7,9 \%$ & $7,3 \%$ \\
\hline 6 & Manajemen Resiko & $13,3 \%$ & $12,7 \%$ & $13,4 \%$ & $13,2 \%$ \\
\hline 7 & Pelaporan Penerapan Tata Kelola Perusahaan & $3,7 \%$ & $4,4 \%$ & $4,6 \%$ & $4,2 \%$ \\
\hline \multicolumn{2}{|r|}{ TOTAL } & $\mathbf{8 1 , 4 \%}$ & $\mathbf{8 3 , 1 \%}$ & $\mathbf{8 8 , 3 \%}$ & $\mathbf{8 4 , 3 \%}$ \\
\hline
\end{tabular}

Sumber: Data Diolah 
Pada Tabel 4 terlihat bahwa dimensi pengungkapan tata kelola perusahaan terkait Dewan Pengawas Syariah (DPS), Dewan Komisaris, Dewan Direksi, Komite serta Manajemen Resiko sebagian besar telah diungkapkan dengan persentase tiap dimensi di atas $10 \%$. Namun dimensi Pelaporan Penerapan Tata Kelola Perusahaan yang sesuai dengan prinsip syariah, meliputi: kerangka kerja tata kelola perusahaan yang baik serta assesment penerapan tata kelola perusahaan yang baik dari pihak internal maupun eksternal, memiliki persentase terendah, yaitu hanya sebesar 4,2\%. Namun secara keseluruhan ratarata skor pengungkapan ICG pada BUS selama periode pengamatan mencapai $84,3 \%$ dan mengalami peningkatan tiap tahunnya, yaitu dari $81,4 \%$ di tahun 2014, meningkat di tahun 2015 menjadi $83,1 \%$ dan selanjutnya meningkat kembali menjadi 88,3\% di tahun 2016 . Nilai rata-rata ICG sebesar $84,3 \%$ cukup baik dan menunjukkan komitmen dari BUS untuk menerapkan good corporate governance serta mengungkapkannya dalam laporan tahunan.

\subsection{Pembahasan}

Berdasarkan hasil penelitian, secara umum dapat dikatakan bahwa BUS telah menerapkan prinsip-prinsip good corporate governance serta mengungkapkannya pada laporan tahunan. Hal tersebut menunjukkan kesadaran masing-masing BUS akan pentingnya penerapan good corporate governance untuk keberlanjutan usaha BUS ke depan. Namun, masih terdapat beberapa indikator ICG yang belum diterapkan dan diungkapkan oleh sebagian besar BUS selama periode pengamatan, antara lain: keberadaan komite tata kelola, sertifikasi audit internal yang dimiliki oleh karyawan, kebijakan penunjukkan auditor eksternal, kerangka kerja terkait audit internal dan kerangka kerja tata kelola perusahaan yang baik serta adanya assessment tata kelola perusahaan yang baik dari pihak eksternal. Bahkan terdapat pula indikator ICG dimana tidak terdapat satupun BUS yang mengungkapkannya dalam laporan tahunan, yaitu: remunerasi anggota komite serta kinerja tiap anggota komite. 
Untuk indikator keberadaan komite tata kelola, hanya Bank Muamalat Indonesia (BBMI) yang telah membentuk komite tata kelola pelaksanaan GCG, guna membantu tugas Dewan Komisaris dalam pelaksanaan good corporate governance serta memperkuat struktur, proses dan hasil tata kelola BBMI.

Dalam kaitannya dengan indikator sistem pengendalian internal berupa audit internal dan eksternal, hanya sebagian kecil BUS yang mengungkapkan kerangka kerja terkait audit internal, sertifikasi audit internal yang dimiliki oleh karyawan serta kebijakan penunjukkan auditor eksternal. Padahal hal ini penting untuk diuraikan sebagai pertimbangan bagi stakeholder dalam penilaian atas efektifitas sistem pengendalian internal BUS.

Adapun pada Dimensi Pelaporan Penerapan Tata Kelola Perusahaan, masih sebagian kecil BUS yang menyediakan informasi kerangka kerja good corporate governance serta penggunaan pihak eksternal dalam penilaian good corporate governance. Sebagian besar BUS melaksanakan selfassessment dalam penilaian penerapan tata kelola pada perusahaannya. Sebagai contoh BUS yang menggunakan pihak eksternal dalam penilaian penerapan good corporate governance adalah Bank Syariah Mandiri (BBSM). BBSM sejak tahun 2011 rutin mengikuti program Corporate Governance Perception Index (CGPI). CGPI merupakan program riset dan pemeringkatan pelaksanaan good corporate governance yang diselenggarakan oleh The Indonesian Institute for Corporate Governance (IICG). Tujuan program CGPI adalah memotivasi perusahaan untuk melaksanakan perbaikan yang berkelanjutan guna meningkatkan kualitas tata kelolanya. Hasil dari penilaian tersebut, BBSM memperoleh predikat sebagai "The Most Trusted Companies". Predikat tersebut memperihatkan komitmen BBSM dalam menerapkan good corporate governance secara berkelanjutan.

Dalam menilai penerapan good corporate governance $\mathrm{di}$ perusahaannya, BUS selain menggunakan self-assessment, perlu kiranya juga menggunakan pihak ekternal yang independen dan kredibel. Beberapa manfaat yang dapat dicapai 
dari penilaian good corporate governance dari pihak eksternal (salah satunya dengan menggunakan CGPI) adalah memperbaiki faktor internal perusahaan yang belum memadai guna meningkatkan kualitas penerapan good corporate governance, memetakan masalah strategis perusahaan guna meningkatkan kualitas penerapan good corporate governance, meningkatkan kesadaran dan komitmen bersama jajaran internal perusahaan dalam mengimplementasikan good corporate governance serta meningkatkan kepercayaan publik terhadap perusahaan.

Secara keseluruhan tingkat pengungkapan ICG BUS dalam laporan tahunannya selama periode pengamatan sudah cukup baik karena mencapai ratarata skor $84,3 \%$ dengan tren yang selalu meningkat per tahunnya. Namun penyempurnaan penerapan good corporate governance sesuai prinsipprinsip syariah harus terus dilaksanakan oleh BUS sebagai sebuah entitas syariah guna perwujudan akuntabilitas syariah kepada Allah SWT, masyarakat serta alam dengan orientasi kepada falah dan kesejahteraan sosial.

\section{KESIMPULAN DAN SARAN}

Penelitian ini menganalisis tingkat pengungkapan Islamic Corporate Governance (ICG) perbankan syariah di Indonesia periode 2014-2016. Corporate Governance Disclosure Index (CGDI) yang dikembangkan Darmadi (2013) digunakan guna mengukur tingkat pengungkapan ICG. Berdasarkan analisis data, diperoleh hasil bahwa tingkat ICG pada BUS selama periode pengamatan mencapai nilai rata-rata sebesar $84,3 \%$ dan mengalami peningkatan tiap tahunnya, yaitu dari $81,4 \%$ di tahun 2014, meningkat menjadi $83,1 \%$ di tahun 2015 dan selanjutnya meningkat kembali menjadi 88,3\% di tahun 2016. Nilai rata-rata ICG sebesar $84,3 \%$ cukup baik dan menunjukkan komitmen dari BUS untuk mengimplementasikan good corporate governance serta mengungkapkannya pada laporan tahunan. Namun penyempurnaan penerapan ICG harus terus dilaksanakan oleh BUS guna perwujudan akuntabilitas kepada Allah SWT, masyarakat serta alam dengan orientasi kepada falah dan kesejahteraan sosial. 
Penelitian ini merupakan penelitian deskriptif kualitatif dengan metode content analysis yang digunakan untuk menganalisis tingkat pengungkapan ICG perusahaan sampel. Untuk

\section{DAFTAR PUSTAKA}

Abu-Tapanjeh, A.M. 2009. Corporate governance from the Islamic perspective: Acomparative analysis with OECD principles. Critical Perspectives on Accounting 20: 556-567.

Charles, P.A dan Chariri, A. 2013. Analisis Pengaruh Islamic Corporate Governance terhadap Pengungkapan Corporate Social Responsibility (Studi Kasus pada Bank Syariah di Asia). Diponegoro Journal Of Accounting, Vol. 2 (No. 1): 168182.

Choudury, M.A., dan Hoque, M.Z. 2006. Corporate governance in Islamic prespective. Corporate Gorvernance Vol. 6 (No. 2): 116-128.

Darmadi, S. 2013. Corporate governance disclosure in the annual report: An exploratory study on Indonesian Islamic banks. Humanomics, Vol. 29 ( No. 1): 4-23.

Haniffa, R. 2002. Social Reporting Disclosure: An Islamic Perspective. Indonesian Management \& Accounting Research, Vol.1 (No. 2): 128146. penelitian selanjutnya, dapat dilakukan pengujian lebih lanjut secara statistik atas hasil content analysis yang telah diperoleh guna memperoleh kesimpulan penelitian yang lebih teruji.

Jumansyah dan Syafei, A., W. 2013. Analisis Penerapan Good Governance Business Syariah dan Pencapaian Maqashid Shariah Bank Syariah di Indonesia. Jurnal Al-Azhar Indonesia Seri Pranata Sosial, Vol . 2 ( No. 1): 25 - 38.

Komite Nasional Kebijakan Governance (KNKG). 2011. Pedoman Umum Good Governance Bisnis Syariah. Jakarta: Komite Nasional Kebijakan Governance

Majid, N. A., Sulaiman, M., dan Ariffin, N. M. 2011. Developing a Corporate Governance Disclosure Index for Islamic Financial Institutions. 8th International Conference on Islamic Economics and Finance: 1-25.

Mannan, M.A. 1980. Islamic Banking: Definition, Objectives, Method and Functions. Dacca: Islamic Economic Research Bureau.

Organisation for Economic Cooperation and Development (OECD). 2015. G20/OECD Principles of Corporate Governance. Ankara: Organisation for Economic Cooperation and Development 
Otoritas Jasa Keuangan (OJK). 2017. Roadmap Pengembangan Keuangan Syariah Indonesia 2017-2019. Jakarta: Otoritas Jasa Keuangan (OJK).

Otoritas Jasa Keuangan (OJK). 2017. Statistik Perbankan Syariah Oktober 2017. Jakarta: Otoritas Jasa Keuangan (OJK).
Siddiqui, M.N. 1980. Components of Islamic Banking. Ins, Thought of Islamic Bank. Dhaka, Bangladesh

Sulaiman, M., Majid, N. A., dan Arifin, N. M. 2015. Corporate Governance of Islamic Financial Institutions in Malaysia. Asian Journal of Business and Accounting, Vol. 8 (No. 1): 65 93.

www.ojk.go.id 


\section{Lampiran \\ Indeks Islamic Corporate Governance (ICG) Disclosure}

\begin{tabular}{|c|c|c|}
\hline \multicolumn{2}{|r|}{ Dimensi } & Item Pengungkapan \\
\hline $\mathbf{A}$ & $\begin{array}{l}\text { Dewan Pengawas } \\
\text { Syariah }\end{array}$ & 1. Nama anggota \\
\hline & & 2. Posisi/Jabatan anggota \\
\hline & & 3. Foto anggota \\
\hline & & 4. Profil anggota \\
\hline & & 5. Jumlah rapat yang diadakan \\
\hline & & 6. Kehadiran anggota dalam rapat \\
\hline & & 7. Remunerasi anggota \\
\hline & & 8. Tugas dan tanggung jawab dewan \\
\hline & & 9. Kepatuhan produk dan jasa dengan ketentuan syariah \\
\hline & & 10. Kepatuhan laba-rugi dengan ketentuan syariah \\
\hline & & 11. Prosedur pemeriksaan \\
\hline & & 12. Rekomendasi kepada manajemen \\
\hline \multirow[t]{13}{*}{ B } & Dewan Komisioner & 13. Nama anggota \\
\hline & & 14. Posisi/Jabatan anggota \\
\hline & & 15. Foto anggota \\
\hline & & 16. Profil anggota \\
\hline & & 17. Independensi anggota \\
\hline & & 18. Terdiri dari sedikitnya 50\% anggota independen \\
\hline & & $\begin{array}{l}\text { 19. Beberapa fungsi komisioner/direktur yang dipegang } \\
\text { oleh anggota }\end{array}$ \\
\hline & & 20. Jumlah rapat yang diadakan \\
\hline & & 21. Kehadiran anggota dalam rapat \\
\hline & & 22. Remunerasi anggota \\
\hline & & 23. Tugas dan tanggung jawab dewan direksi \\
\hline & & 24. Kepemilikan saham anggota \\
\hline & & 25. Rekomendasi kepada manajemen \\
\hline \multirow[t]{9}{*}{$\mathbf{C}$} & Dewan Direksi & 26. Nama anggota \\
\hline & & 27. Posisi/Jabatan anggota \\
\hline & & 28. Foto anggota \\
\hline & & 29. Profil anggota \\
\hline & & 30. Jumlah rapat yang diadakan \\
\hline & & 31. Kehadiran anggota dalam rapat \\
\hline & & 32. Remunerasi anggota \\
\hline & & 33. Tugas dan tanggung jawab dewan \\
\hline & & 34. Kepemilikan saham anggota \\
\hline \multirow[t]{5}{*}{$\mathbf{D}$} & Dewan Komite & 35. Keberadaan komite audit \\
\hline & & 36. Keberadaan komite remunerasi dan nominasi \\
\hline & & 37. Adanya komite monitoring risiko \\
\hline & & 38. Adanya komite tata kelola perusahaan \\
\hline & & 39. Tugas dan tanggung jawab masing-masing komite \\
\hline
\end{tabular}




\begin{tabular}{|c|c|c|}
\hline & & 40. Laporan komite dalam laporan tahunan \\
\hline & & 41. Nama anggota \\
\hline & & 42. Posisi/Jabatan anggota \\
\hline & & 43. Foto anggota \\
\hline & & 44. Profil anggota \\
\hline & & 45. Sebagian besar anggota independen \\
\hline & & 46. Jumlah rapat yang diadakan \\
\hline & & 47. Kehadiran anggota dalam rapat \\
\hline & & 48. Remunerasi anggota \\
\hline & & 49. Kinerja tiap anggota \\
\hline $\mathbf{E}$ & $\begin{array}{l}\text { Pengendalian Internal } \\
\text { dan Audit Eksternal }\end{array}$ & 50. Laporan pengendalian internal dalam laporan tahunan \\
\hline & & 51. Adanya divisi audit internal \\
\hline & & 52. Kerangka kerja audit internal \\
\hline & & 53. Tugas dan tanggung jawab divisi audit internal \\
\hline & & $\begin{array}{l}\text { 54. Sertifikasi audit internal yang dipegang oleh } \\
\text { karyawan }\end{array}$ \\
\hline & & 55. Kebijakan penunjukan auditor eksternal \\
\hline & & 56. Auditor eksternal yang ditunjuk oleh bank \\
\hline & & 57. Kinerja divisi audit internal \\
\hline $\mathbf{F}$ & Manajemen Resiko & 58. Laporan manajemen risiko dalam laporan tahunan \\
\hline & & 59. Adanya divisi manajemen risiko \\
\hline & & 60. Kerangka kerja manajemen risiko \\
\hline & & 61. Tugas dan tanggung jawab divisi manajemen risiko \\
\hline & & $\begin{array}{l}\text { 62. Sertifikasi manajemen risiko yang dimiliki oleh } \\
\text { karyawan }\end{array}$ \\
\hline & & 63. Manajemen risiko pasar \\
\hline & & 64. Manajemen risiko kredit \\
\hline & & 65. Manajemen risiko likuiditas \\
\hline & & 66. Manajemen risiko operasional \\
\hline & & 67. Profil risiko \\
\hline $\mathbf{G}$ & $\begin{array}{l}\text { Pelaporan Penerapan } \\
\text { Tata Kelola } \\
\text { Perusahaan } \\
\end{array}$ & $\begin{array}{l}\text { 68. Laporan pelaksanaan tata kelola perusahaan dalam } \\
\text { laporan tahunan }\end{array}$ \\
\hline & & 69. Kerangka kerja GCG \\
\hline & & 70. Kode etik \\
\hline & & 71. Penilaian GCG dari pihak internal \\
\hline & & 72. Penilaian GCG oleh pihak eksternal \\
\hline
\end{tabular}

Sumber: Darmadi (2013) 